\title{
SÁMI ROCK ENGRAVINGS FROM THE MOUNTAINS IN LAPONIA, NORTHERN SWEDEN
}

\author{
Tim Bayliss-Smith and Inga-Maria Mulk
}

\section{INTRODUCTION}

In this paper we present a description of some rock engravings that have been discovered by reindeer herders in Padjelanta, on the fringes of the Sarek Mountains in Lapland, northern Sweden. The site has now been registered, but it has not yet been fully researched and is unprotected, so its precise location will not be disclosed. In this paper we shall call it the Padjelanta site. The pictures there include various figures - animals including reindeer, human-like forms, and many patterns difficult to interpret - but the boats are the most striking feature. At least three of the boats are sailing boats, and two of them are depicted in some detail with rudders, an anchor, masts and sails, and occupants. This paper will focus on what the boats themselves represent, without considering the other surrounding and overlapping figures to which the boats may or may not be related.

The depiction of sailing boats in rock art is very unusual. In Scandinavia as a whole there are many thousands of depictions of boats that are known, but almost all are relatively simple forms assumed to be skin (hide) boats, dugout canoes or sewn-plank boats (Mallmer 1989). In Uppland, for example, there are at least 2300 rock carving sites which include about 2000 images of boats, but none of them have masts or sails: "it seems clear that all Bronze Age boats were rowed, paddled or poled and not sailed, although paddles are only distinctly shown on one boat" (Coles 1994: 27). In northern Sweden there are many fewer sites: Ångermanland, Västerbotten and Lapland have only six major sites of rock art, all of them rock carvings located very close to major salmon rivers (Ramqvist 1989). At the best-known site, Nämforsen, all of the 336 boat figures analysed by Hallström (1960) are simple forms depicted either in sin- 
gle or in double lines, and sometimes with ribs. There is no convincing evidence for masts, sails, oars or rudders.

Rather similar boats are depicted on the coasts of Norway, where again most of the pictures date from the Neolithic and Bronze Age. In Trøndelag a steering paddle is sometimes depicted in the boats of the most recent period, which according to Sognnes (1998: 151) was in the Roman Iron Age (about AD 1-400). By this time rowing seems to have replaced paddling as the principal means of propulsion. There is no real evidence for the use of masts and sails in any of the rock art before the 6th century AD (Westerdahl 1995: 42).

In the Nordic world pictures of boats/ships only become frequent again during the Viking Age and later periods. Pictures are found scratched on wood and stone and as graffiti on church walls and in water-mills. Almost all the pictures of sailing ships are found near to the coast, and Christensen (1995) suggests they were the work of men (and probably boys) who belonged to a maritime society and saw sailing ships as important tools for trade and warfare. He suggests that "they carved them as expressions of preoccupation and strong interest, not as symbols" (Christensen 1995: 184).

In contrast the Padjelanta site is in an uninhabited mountain valley above the tree line, more than $10 \mathrm{~km}$ from the nearest large river or lake, and at least $40 \mathrm{~km}$ from the fjords on the coast of Norway opposite the Lofoten-Vesterålen islands. The valley in which the site is located is seldom visited. Apart from a few tourists wandering around the fringes of the Sarek Mountains in the Laponia World Heritage Area, the valley is used only by reindeer herders belonging to Sirkas Sameby, who use the whole of Padjelanta as summer pasture. Before the era of intensive reindeer pastoralism (i.e before c. 1600) the Padjelanta site was within the territory of mobile hunting groups of the Mountain Sámi, whose winter base camps were in the forest zone to the east (Mulk 1994a).

Historical sources which refer to the Sámi before the onset of pastoralism are extraordinarily sparse (Whitaker 1981, 1983; Hansen 1990), while archaeological evidence survives for only a few aspects of the material culture (Mulk 1994a, 1996). From these data it seems unquestionable that small boats have been essential for Sámi mobility for millennia, but there is no evidence for the use of 
large sailing boats by the Mountain Sámi, past or present, on the lakes and rivers of the inland area. The images of sailing boats at the Padjelanta site therefore demand an explanation which places them into a wider geographical and historical context, and which considers their cultural and symbolic as well as their iconic meaning. This paper represents a first step in this direction, extending the much briefer accounts that have already been published (Bayliss-Smith \& Mulk 1998; Mulk 1998; Mulk \& Bayliss-Smith \& Nordqvist 1998).

\section{THE SITE OF THE PADJELANTA ROCK ENGRAVINGS}

\section{Environment}

The Padjelanta site is located at the side of a mountain valley between 700-800 m, where a rock outcrop of 'roche moutonnée' formation has been smoothed by glacial action to produce near-vertical slabs of bare rock including exposures of a soft rock similar to soapstone and containing asbestos. Although much fissured, these exposures include many smooth surfaces suitable for engraving, and the rock is soft enough to be incised with a knife or axe. In summer the rocks are often wet from rain or from meltwater dripping down from above. In some years (e.g. 1993) the surfaces that have been engraved are obscured by snowdrifts until July, and again from October onwards.

The main expanse of pictures is on a rock face that faces due south. The pictures extend for a distance of $4 \mathrm{~m}$ and cover most of the rock from near to the ground to about $1.5 \mathrm{~m}$ above ground level. Excavations were carried out in this zone (Zone D) to a depth of about $25 \mathrm{~cm}$, and did not reveal any rock engravings below the presentday ground level. The adjacent rock surfaces have been quarried in the past for soapstone. In the most recent quarry (Zone C), which has a rock surface not yet darkened by surface weathering and with very few lichens, there are various graffiti (Figure 1). One appears to be a date, ' $1673 \mathrm{VI}$ ', beneath which someone has more recently added '1990'. A second image is a calf-marking diagram, showing the pattern of cuts on the ear of a domesticated reindeer that denotes to whom the animal belongs. Another is the outline of 


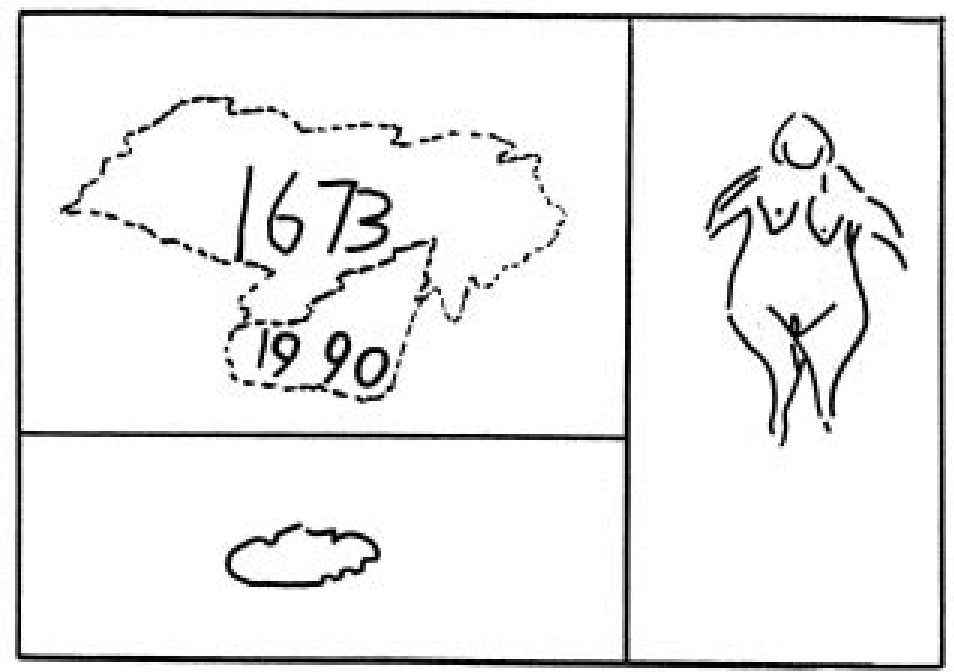

Figure 1. Graffiti from the Borjjas site: dates, a calf-marking diagram, and a nude woman.

a fat, naked woman viewed from the front (Figure 1). In contrast to these images, all of which we can assume date from recent centuries, the boat pictures are on weathered rock surfaces darkened by the growth of algae. The images are partially covered with lichens and have the appearance of being considerably older than the graffiti in Zone $\mathrm{C}$.

The vegetation of the area is alpine tundra classified as grass heath dominated by Carex bigelowii and Juncus trifidus (von Sydow 1982). The nearest birch trees are several kilometres away down-valley. There are small lakes near to the site, but they are frozen for 6-8 months of the year and hardly need to be crossed by boat. It is a long way from the nearest large lakes, which are along the upper reaches of the Stora Lule river valley, today dammed to form Akkajaure.

\section{Wider context}

In these mountains there are numerous examples of prehistoric settlement sites, including examples of the so-called stállo sites 


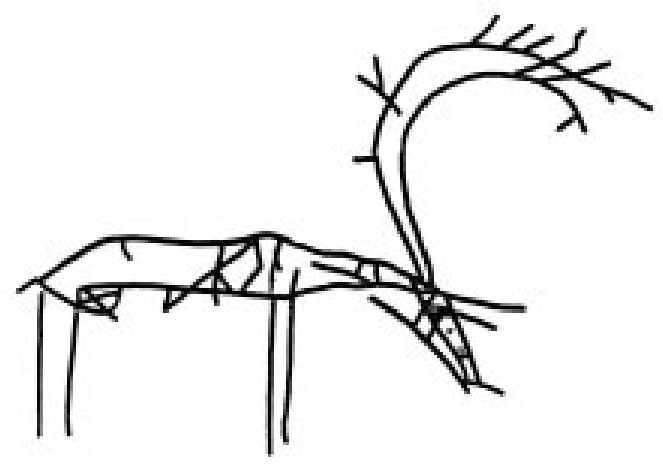

$\stackrel{\text { scale }(\mathrm{cm})}{0} \quad \underbrace{1} \quad 10$

Figure 2. A reindeer from the Padjelanta site (D7). The animal appears to be male, and the lines drawn on its head and back probably represent harness and saddle, respectively.

which are now generally recognised as being seasonal camps of the Mountain Sámi who were hunting wild reindeer using pitfalls and tame reindeer as hunting decoys and draft animals. There is an engraving of a reindeer at the Padjelanta site which appears to be contemporary with the boat engravings. It is a male animal with a harness and pack saddle (Figure 2). The stállo sites were mostly occupied in the late period of Sámi hunting culture, when an increasing use of summer hunting grounds in the mountains can be linked to an expansion in the fur trade during late Iron Age and Nordic Medieval times, c. 500-1400 AD (Mulk 1988, 1994a, 1996; Storli 1993; Mulk \& Bayliss-Smith 1998). The sacrificial site at Vidjakuojka is not far from the Padjelanta site, and was a focus for Sámi ritual activity at this same period (Serning 1956; Manker 1957; Mulk 1994b).

Those Sámi living on the Norwegian coast adjacent to the LofotenVesterålen islands had been influenced by some aspects of Nordic culture since the early Iron Age (Jørgensen \& Olsen 1987), and there is evidence for a substantial linguistic influence from the 4 th century AD onwards (Wiklund 1947). In addition to farming some of the Norsemen were plundering, tax levying and trading with 
the Sámi population of hunters and fishers. These activities have been viewed by some historians as the means whereby rich farmers and Viking chiefs acquired their wealth. Alternatively it can be argued that in fact the main form of interaction between Norsemen and Sámi was gift exchange, which provided a better means for both parties to establish stable and mutually beneficial relations (Stenvik 1980; Whitaker 1981; Odner 1983, 1985; Hansen 1990; Mulk 1996).

During the Viking and Medieval periods (c. 800-1500) there was an increase in long-distance sea trade and a growing assimilation of the Coastal Sámi in north Norway into a more sedentary life style (Kolsrud 1961; Nielssen 1990). Inland, however, the Mountain Sámi group associations (sijdda) continued to be engaged in reindeer hunting in connection with the fur trade. Mulk's (1994a, 1996) reconstruction suggests that the regional network (vuobme) of the upper Lule river valley contained four sijdda, one of which (Sirkas) controlled the summer hunting grounds in Padjelanta where the rock-art site is located. The sijdda society that developed during the 1st millennium $\mathrm{AD}$ was organised to achieve cooperation among specialised task groups, redistribution and satisfactory exchange relationships with outsiders. The evidence from the sacrificial sites suggests that the trade of the Mountain Sámi was eastwards with Finns, Karelians and Russians as well as westwards with the Norwegians (Mulk 1994b, 1996).

To summarise, the site of the Padjelanta rock engravings has so far provided no direct archaeological evidence for its prehistory. The animal and human figures from the site are also unhelpful in this respect (Figure 3). However the location of the site does provide some clues. It is in an area of summer reindeer pastures controlled by a Mountain Sámi sijdda that was based on one of the major river and lake systems of northern Sweden. It is also close to the territorial boundary between coastal populations and the Mountain Sámi. Until recent centuries the dominant economy of the inland regions was wild reindeer hunting, and seasonal use of the mountains was connected with the fur trade during the millennium that ended with the onset of intensive pastoral nomadism in the 17th century. This fur trade connected the Mountain Sámi both with communities living far to the east and with Coastal Sámi and the Nordic settlers to the west. 


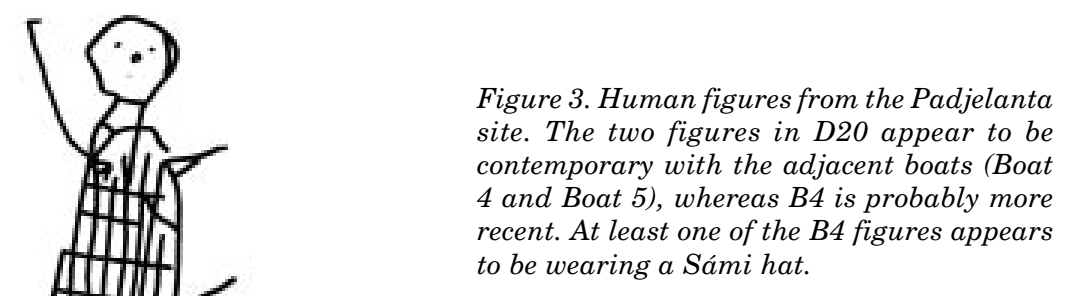

Figure 3. Human figures from the Padjelanta site. The two figures in D20 appear to be contemporary with the adjacent boats (Boat 4 and Boat 5), whereas B4 is probably more to be wearing a Sámi hat.

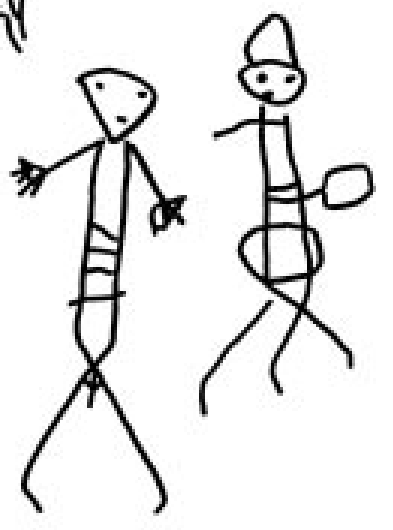

scale $(\mathrm{cm})$

0

\section{THE PADJELANTA BOATS}

\section{Fieldwork and methods}

The boats described in this paper are those recognised and recorded during fieldwork at the Padjelanta site carried out by Ájtte $\mathrm{Mu}$ seum, Jokkmokk, in August 1992, July 1993 and July 1998. The main techniques used were mapping, photography and the direct tracing of the pictures on to transparent paper. No attempt was made to clean the soapstone rock surface or to mark it in any way. Some areas of the rock are partially obscured by the growth of lichen, and if cleaned some further details might be revealed. Apart from limited excavations in the main area of rock engravings to see if they continued underground, no archaeological work has been done at the site. 
In this paper we focus on the pictures of boats. We use the English word 'boat' rather than 'ship' to describe the Padjelanta vessels, although we recognise that the two words are to some extent interchangeable. McGrail (1993: 20-21) suggests that we should define 'small boats' as being those that have an overall length of less than $7 \mathrm{~m}$, while 'boats' are 7-12 $\mathrm{m}$ in length. Those in the next size category $(12-20 \mathrm{~m})$ can be called either 'large boats' or 'small ships' depending on whether or not they have ocean-going capabilities. The intended size of the Padjelanta boats cannot be accurately assessed, although some are clearly meant to be larger than others. We conclude below that the closest equivalent to the larger Padjelanta boats is a coastal trader like the Skuldelev 3 'great boat' (storbait, Swedish) found at Roskilde, so that the term 'boat' is the one that we use throughout this discussion.

\section{The hulls of the six boats}

Six boats can be recognised at the Padjelanta site, some depicted more clearly than others (Figure 4). From left to right we have numbered them 1-6, and their actual dimensions on the rock are shown in Table 1 and Figures 5-10. The pictures all show boats viewed from the side. Their hulls are 'double-ended', in other words symmetrical fore and aft, and with strongly curved stems and sterns. Boat 4 even has an inwards curve at both ends, very reminiscent of the shape of the hulls of the Viking funeral ships at

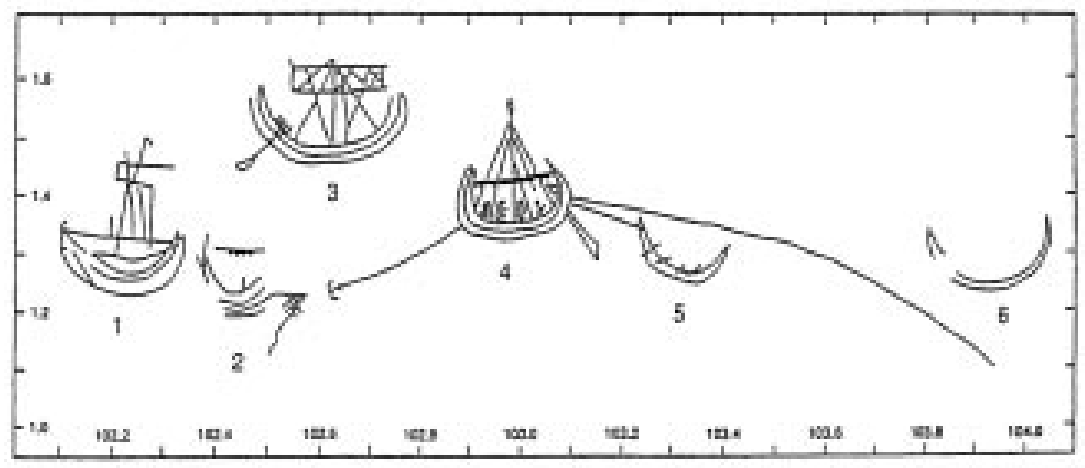

Figure 4. Co-ordinates and relative positions of the six Padjelanta boats. 


\begin{tabular}{c|ccc} 
Boat & $\begin{array}{l}\text { Length of hull } \\
\text { as depicted } \\
(\mathrm{mm})\end{array}$ & $\begin{array}{l}\text { Number of lines } \\
\text { defining hull }\end{array}$ & $\begin{array}{l}\text { Depth of hull } \\
\text { as depicted } \\
\text { (mm) }\end{array}$ \\
\hline 1 & 232 & 5 & 64 \\
2 & $\mathrm{c} .140$ & 4 & 60 \\
3 & 304 & 3 & 31 \\
4 & 236 & 2 & 42 \\
5 & 189 & 2 & 25 \\
6 & 252 & 2 & 14
\end{tabular}

Table 1. Dimensions of the hulls of the six boats.

Oseberg and Kvalsund 2 (McGrail 1998: 246). In the case of Boat 4, the slightly separated points of the upper and lower parts of the hull at each of their curved ends are perhaps intended to show the existence of separate stern posts and stem posts. The hulls are drawn with single outlines in two cases (Boats 5 and 6). In another two cases (Boats 3 and 4), the shape of the hull is divided into two parallel 'layers' and there appear to be three layers of hull in the case of Boats 1 and 2 - although these two are not at all clearly drawn, or perhaps are not so well preserved. Where 'layers' of hull are shown the style of drawing is probably an attempt to represent lap-strake (clinker) construction methods.

In three cases the boats have masts, yards and furled sails, and these also are viewed from the side. As the shapes of the boat hulls are symmetrical one cannot readily distinguish stem from stern unless the pictures provide additional information, as in the case of Boats 3, 4 and 5. On the rock the boats vary in length from 140 $\mathrm{mm}$ (Boat 2) to $304 \mathrm{~mm}$ (Boat 3). The depth of the boats' hulls varies from 14 to $64 \mathrm{~mm}$. There appears to be no attempt to portray a water surface or waves.

\section{Masts, rigging, sails and yards}

Details of masts, rigging, sails and yards are shown in Table 2. Masts are clearly drawn for only two of the boats (Boats 3 and 4). In the case of Boat 1 there is a confusion of scratched lines showing part of a sail and, probably, a mast. The mast of Boat 4 has a height 


\begin{tabular}{c|ccccc} 
Boat & Mast & $\begin{array}{l}\text { Height of } \\
\text { mast as } \\
\text { depicted } \\
(\mathrm{mm})\end{array}$ & $\begin{array}{l}\text { Lines of } \\
\text { rigging } \\
\text { (number) }\end{array}$ & Yard & $\begin{array}{l}\text { Length of } \\
\text { yard as } \\
\text { depicted } \\
(\mathrm{mm})\end{array}$ \\
\hline 1 & yes & ca.113 & traces & unclear & - \\
2 & unclear & - & unclear & yes & 105 \\
3 & yes & 131 & yes (ca.3) & yes & 218 \\
4 & yes & 185 & yes (7) & yes & 166 \\
5 & no & - & no & no & - \\
6 & unclear & - & no & unclear & -
\end{tabular}

Table 2. Details of masts, rigging, sails and yards of the six boats.

of $185 \mathrm{~mm}$, while that of Boat 3 is $131 \mathrm{~mm}$. These heights represent the visible part of the mast that is drawn rising vertically above the upper line of the hull. In all cases the masts are located at about the mid-point of the hull.

At least two of the boats are shown rigged, with symmetrical forestays and backstays. Boat 4 has in addition to a forestay and backstay two other rigging lines (perhaps shrouds), again symmetrically drawn around the vertical line of the mast.

There is the hint of a square sail set above Boat 1 , but only the lefthand part is shown or is visible (Figure 5). Boat 2 (which apparently has no mast) has a sail furled along a yard $105 \mathrm{~mm}$ in length (Figure 6). Boat 3 seems to have a sail half unfurled from a yard that is $131 \mathrm{~mm}$ long, with some suggestion of a criss-cross pattern of ropes on the sail (Figure 7). The best-drawn boat, Boat 4, has a fully furled sail along a yard that is less than halfway hoisted up the mast. The yard extends the whole length of the hull from stem to stern, and is shown $185 \mathrm{~mm}$ in length. At the top of the Boat 4's mast is a flag $24 \mathrm{~mm}$ high and $7 \mathrm{~mm}$ wide. Boat 4 is clearly shown as being anchored, the anchor line extending out from the stem of the boat on the left-hand side (i.e. to the west). Very logically, the flag is shown as blowing in the opposite direction, towards the boat's stern on the right-hand (eastern) side (Figure 8). 


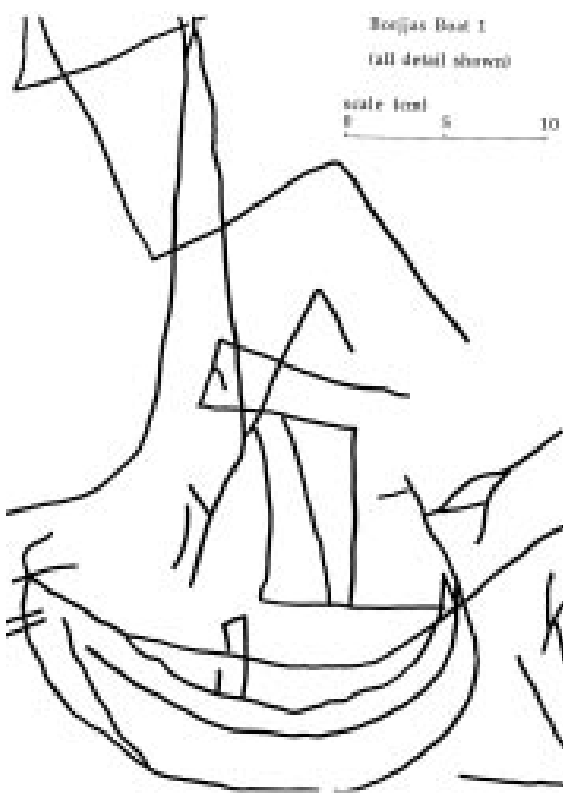

Figure 5. Padjelanta Boat 1 (D10) and an adjacent obscure figure (D9).
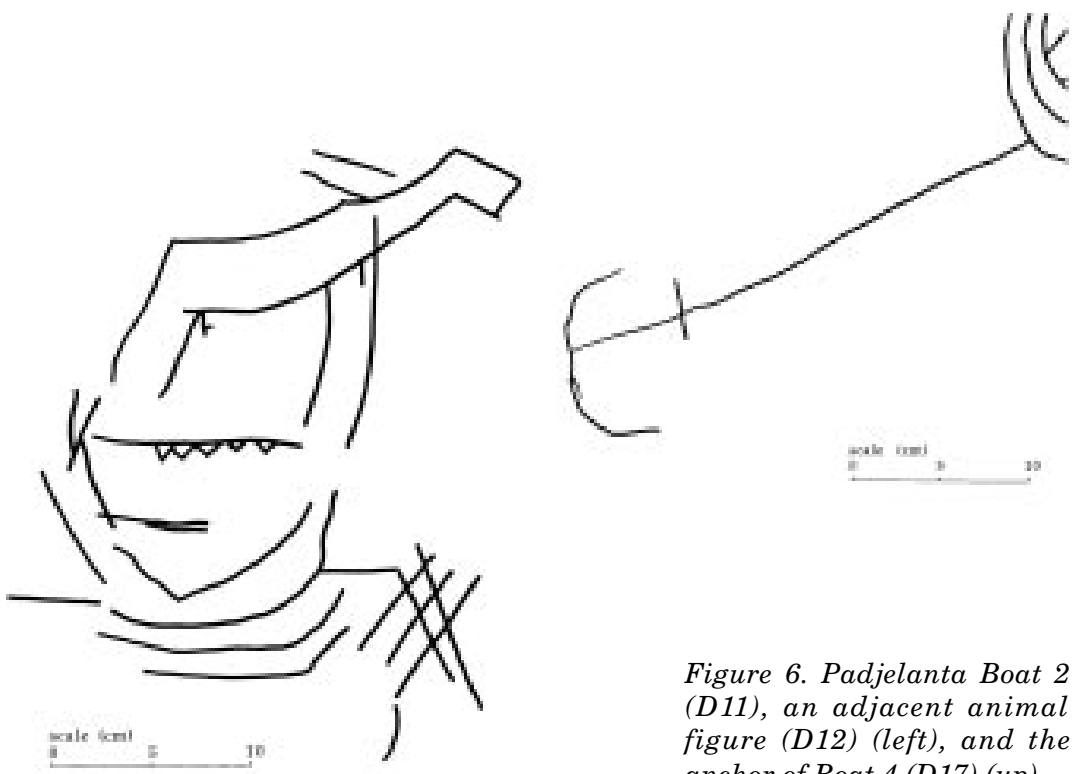

Figure 6. Padjelanta Boat 2 (D11), an adjacent animal figure (D12) (left), and the anchor of Boat 4 (D17) (up). 


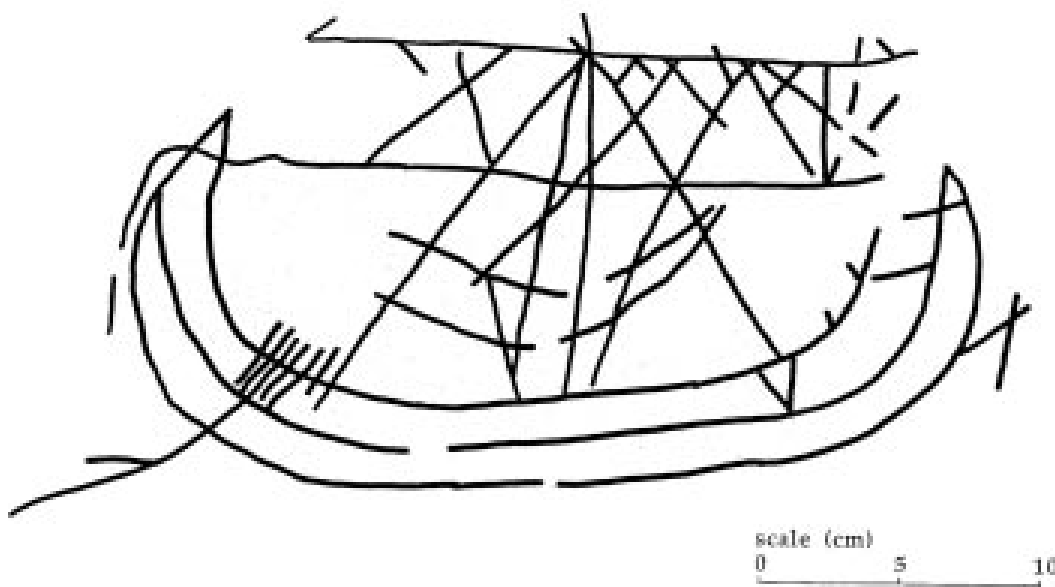

Figure 7. Padjelanta Boat 3 (D13).

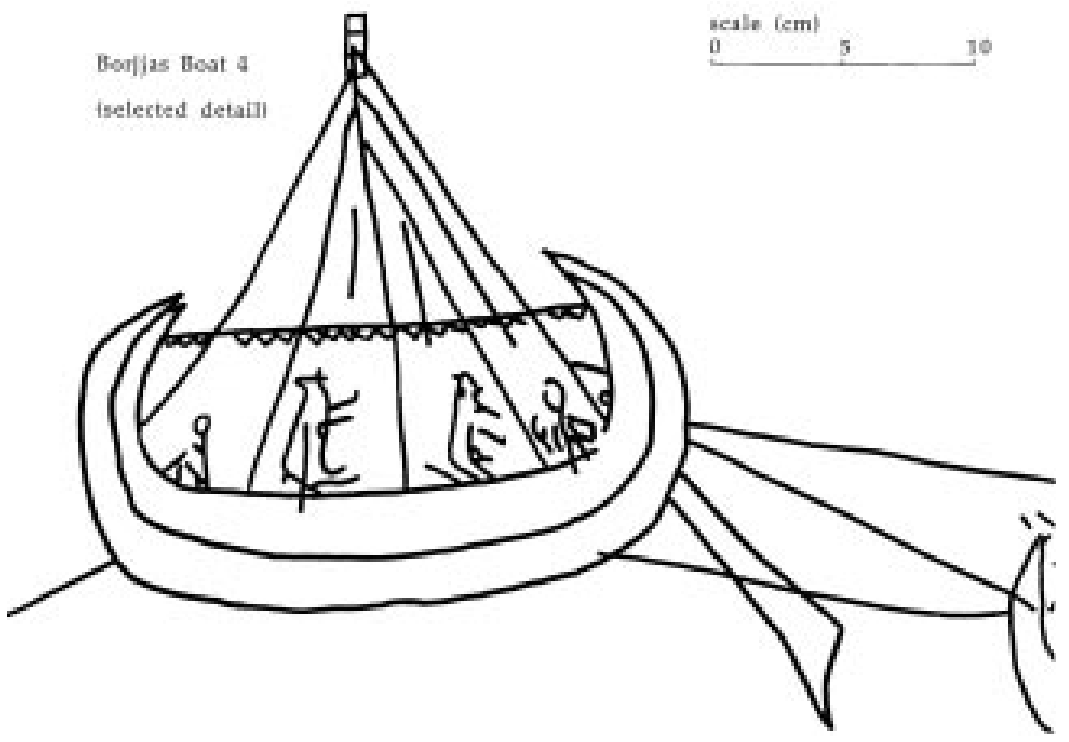

Figure 8. The hull, furled sail, rudder and occupants of Padjelanta Boat 4 (D17). 


\section{Rudders and oars}

Boats 3 and 4 both provide convincing evidence of rudders. The one in Boat 3 could be called a steering oar, but in the case of Boat 4 what is depicted is clearly a side-rudder. It has been carefully drawn and is deeply engraved into the rock, and is shown extending a long way $(110 \mathrm{~mm})$ below the hull. Its considerable length (like the size of the anchor) suggests the artist is emphasising its presence by deliberate exaggeration. The position of the rudder in the boat, its distinctive shape, and the angle it subtends from the vertical are significant details. The rudder is at the right-hand end of Boat 4 and defines its stern, whereas the anchor is at the opposite end. The rudder is not shown as overlapping the hull on the visible side of the boat and it seems very likely, therefore, that it is intended as a side-rudder hanging down on the hidden, starboard side of the boat, next to the stern.

Boat 4 is connected by a towline to Boat 5 , which is smaller, has no mast, and appears to be a rowing boat. Consistent with this view is the presence of four oblique lines which overlap the hull and must represent oars (Figure 9).

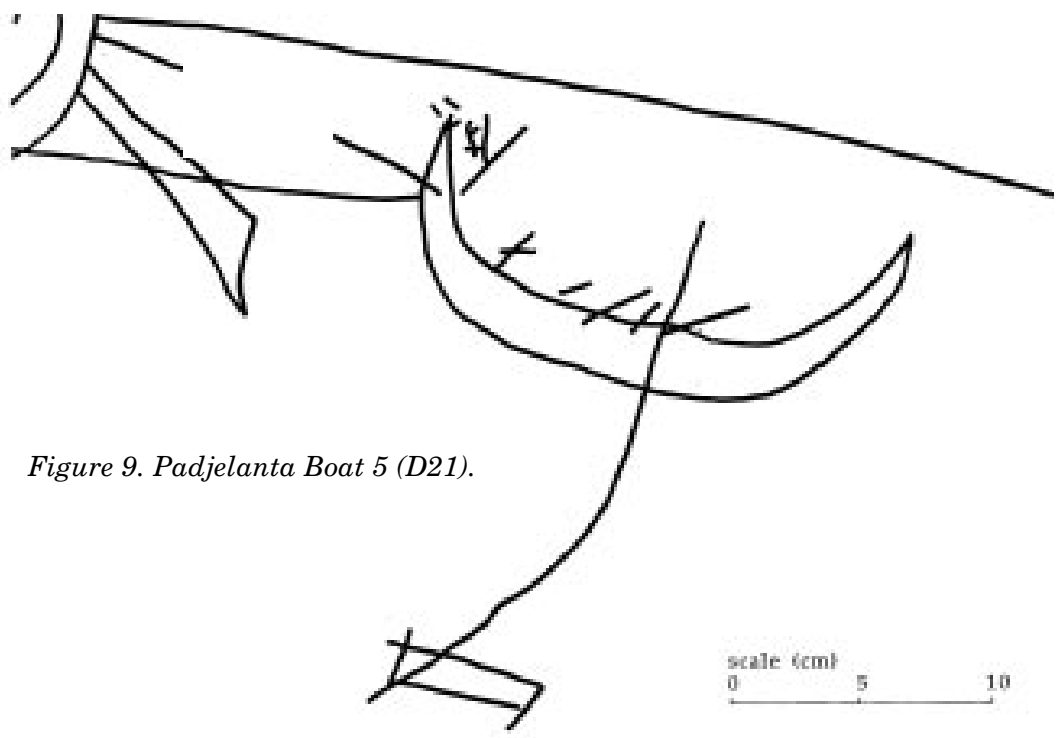




\section{Towlines, mooring lines and anchors}

Only Boat 4 provides a clear depiction of mooring lines. From the stem there is an almost straight line extending out westwards for $290 \mathrm{~mm}$, and connecting the boat to an anchor. The anchor is clearly drawn at an enlarged scale compared to the boat, with long curved arms and a stock at right angles to the shank. It is shown as lying almost horizontal, as if on the sea bed.

As well as its anchor line Boat 4 is also connected to a smaller rowing boat or dinghy (Boat 5), which is shown as drifting downwind towards the east. The connection is a $140 \mathrm{~mm}$ length of towline, shown clearly as looping around the stem of the smaller boat. In addition there is also drawn a line extending a very long way eastwards from the stern of Boat 4. This line runs almost straight for $250 \mathrm{~mm}$, and then dips downwards more steeply for another $255 \mathrm{~mm}$, before petering out somewhere underneath Boat 6 (Figure 10) and very close to present-day ground level. There is no sign of anything at the end, but a net, a mooring or even another anchor is perhaps what was intended.

\section{Occupants}

About fifteen vertical strokes extending upwards from the hull of Boat 3 may be intended to represent crew, but this interpretation is uncertain as the details are only faintly preserved. It is Boat 4 which has clear evidence of figures sitting or standing inside the boat. The vertical lines of the boat's rigging define four spaces, each of which is occupied by one figure. The scratches that define these figures are frustratingly faint, and they can easily be confused with natural cracks in the rock. However, it is certain that four figures can be identified, of which the two central ones appear to be animals each with two horns/antlers and four legs. Unless more details can be revealed by cleaning the rock surface of encrusting lichens, little can be stated with certainty about the animals, which might be reindeer, cattle or sheep. The human figures are also unclear.

There is a large human figure standing outside and to the right of Boat 3 , carrying in one hand a bow or possibly a drum, and in the other hand a spear, paddle or net . The intended connection, if any, 


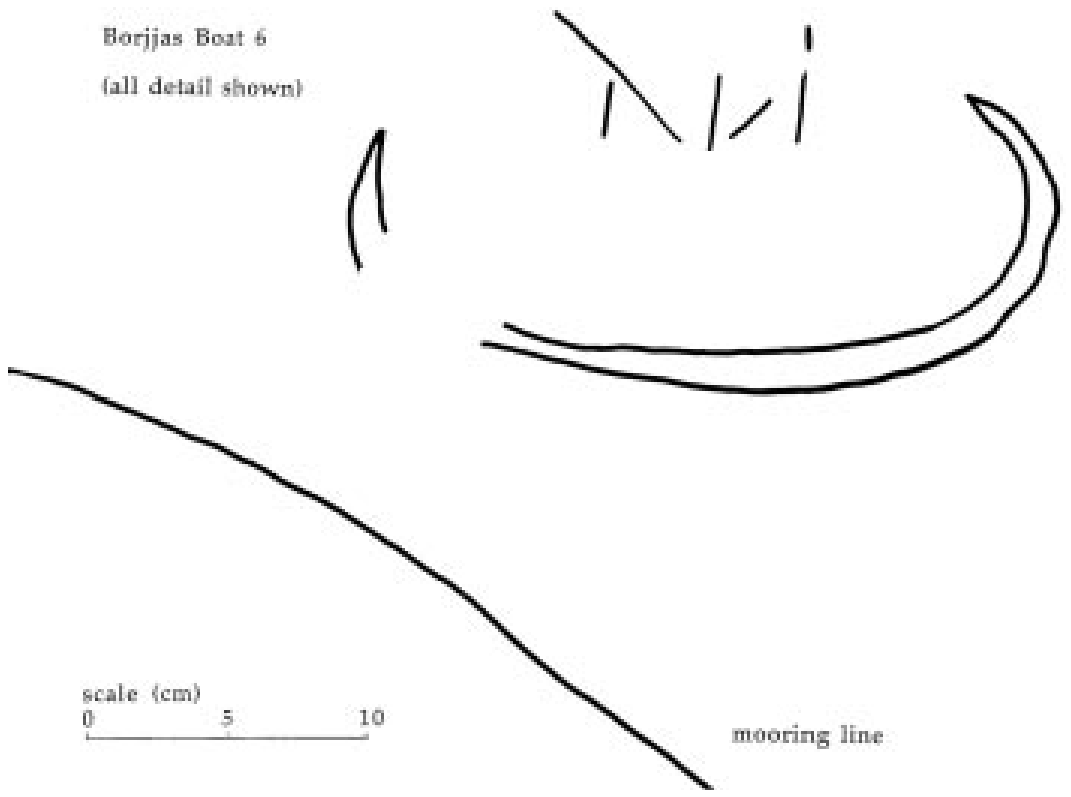

Figure 10. Human figure (D15) situated between Boats 3 and 4, Padjelanta site.

between this figure and Boats 3 and 4 is unclear, but the three drawings have the appearance of being contemporary.

\section{COMPARISON WITH OTHER BOATS}

Taken together, the six images in the Padjelanta rock engravings provide us with a substantial amount of information about the type of boat that is being portrayed. Of course the boats are images constructed in the imagination of the artist. On the other hand several of the boats are so carefully drawn and provide such a wealth of detail, that it seems likely that the artist intended to draw them in a naturalistic way. This does not mean that all details are drawn at the same scale: in Boat 4 the size of the anchor and the length of the side rudder seem exaggerated compared to the other features. There is a parallel in the kind of caricature sometimes found in much older rock art in northern Scandinavia. Bakka (1975: 28), for example, describes an elk figure at Hammer, Nord-Trøndelag, as 
having "the exaggeration of the head [which] agrees with the very best of naturalistic caricature: distortion of proportion with the aim of emphasising the specific characteristics".

To test whether or not the Padjelanta boat pictures are representations of real boats we can make comparisons using information from historical and archaeological evidence and from other iconic representations. If there is a match then we can hope to answer three questions. Firstly, what kind of boat is being represented at the Padjelanta site? Secondly, if these images do portray accurately certain boats from the real world, where were those boats originally seen? Thirdly does the appearance of the Padjelanta boats suggest an estimated date for these pictures? The history of SámiNordic interaction in this region provides part of the context within which these questions can be tackled.

\section{Sámi/Nordic interaction}

There is no clear evidence that the Padjelanta region has been used in prehistory by any groups other than the Sámi and their ancestors. It therefore seems very likely that the rock engravings at this site belong to Sámi culture, and that the pictures were drawn by persons with an intimate knowledge of small boats. Sámi hunting

\begin{tabular}{|c|c|c|c|c|c|c|c|}
\hline Boat & $\begin{array}{l}\text { Side } \\
\text { rudder }\end{array}$ & $\begin{array}{l}\text { Lines for } \\
\text { mooring }\end{array}$ & Anchor & Towline & Oars & $\begin{array}{l}\text { Other } \\
\text { items }\end{array}$ & $\begin{array}{l}\text { Pass- } \\
\text { engers }\end{array}$ \\
\hline 1 & possibly & no & no & unclear & no & unclear & unclear \\
\hline 2 & no & possibly & no & possibly & no & net? & none \\
\hline 3 & yes & no & no & no & possibly & $\begin{array}{c}\text { unfurled } \\
\text { sail }\end{array}$ & $\begin{array}{c}\text { possible } \\
\text { crew }\end{array}$ \\
\hline 4 & yes & yes & yes & $\begin{array}{l}\text { yes, to } \\
\text { Boat } 5\end{array}$ & no & $\begin{array}{c}\text { flag at } \\
\text { mast- } \\
\text { head }\end{array}$ & $\begin{array}{c}\text { yes: } 2 \\
\text { human, } 2 \\
\text { animal }\end{array}$ \\
\hline 5 & no & no & no & $\begin{array}{c}\text { yes, from } \\
\text { Boat } 4\end{array}$ & yes (4) & none & none \\
\hline 6 & no & no & no & no & no & none & none \\
\hline
\end{tabular}

Table 3. Other features of the six Padjelanta boats. 
culture inherited the long tradition of watercraft that is shown in the Stone Age and Bronze Age rock art, and during Iron Age times the technology developed still further. Details of Sámi boatbuilding techniques are provided by Westerdahl (1987), who uses historical sources from the 13th-17th centuries and also reviews the archaeological data for nine excavated Sámi boats that are dated from the 7 th-19th centuries.

Wiklund (1947) and Nesheim (1967) have studied the influence upon language of contacts between the Sámi and their neighbours. Nesheim's (1967) conclusion is that the linguistic evidence suggests that the ancient boats of the Sámi were probably skin-boats with a short, broad steering oar (maelle, from an old Finno-Ugric word). The name for sail (bårjås or borjjas), however, was taken from Primitive Finnish, while "the transition to wooden boats and the further development of these boats seems due to Norse influence, according to the testimony of the language" (Nesheim 1967: 159). A great part of Sámi boat terminology is of Primitive Norse origin.

Borgos and Torgvaer (1998: 110) suggest that in north Norway (Helgeland) the main period for this interaction was between 300$600 \mathrm{AD}$, and that the first opportunity for these transfers was probably in the inner coastal zone where wood for boatbuilding was available. In the Lofoten-Vesterålen there is archaeological evidence for Nordic influence going back to at least 300 AD (Sjøvold 1962; Johansen 1976). From this point onwards, either by colonisation or because of the adoption of the new culture by pre-existing groups, the coastal fringes were occupied by persons of Nordic ethnicity, intermingled in many areas with Coastal Sámi (Kolsrud 1961; Hansen 1990).

The distribution of Nordic graves suggests that in the early Iron Age (before c. $400 \mathrm{AD}$ ) farming settlement was restricted to the outer coastal area, i.e. the Lofoten islands and the mouths of fjords (Sjøvold 1962; Nielssen 1990). In the Lofoten-Vesterålen area pollen evidence indicates that farming reached its most sustained level of activity in the 6th century, with a marked expansion in barley cultivation (Vorren \& Nilssen \& Mørkved 1990: 98). There was much farm desertion in the 7th century, but agriculture continued uninterrupted in the vicinity of important chieftain centres like Borg on Vestvågøy (Vorren \& Nilssen \& Mørkved 1990: 99). It was in 
this later Iron Age period that farming began at places like Ibestad and Arstad in the inner zone of fjords (Vorren \& Nilssen \& Mørkved 1990; Moe 1991). Nordic settlement spread into fjords that had potential farmland and also land route connections which could facilitate trade with the Sámi (Kolsrud 1961; Sjøvold 1974: 335; Hansen 1990). However in many areas, including the smaller fjords leading from Tysfjord, the inner zone remained the territory of Coastal Sámi (Nielssen 1990). These people absorbed aspects of Nordic culture and language but remained primarily "fishers and bird-catchers and hunters", according to Ottar's account of about 880-890 (Lund 1984: 19). As well as their trade with the Nordic farmers, the Coastal Sámi also intermarried and had exchange relations with the Mountain Sámi (Hansen 1984, 1990).

Trade generated wealth for all parties. Several hoards of silver objects dating from Viking times (10th-11th c.) have been found, located "in the outer coastal area ... where the old traffic line along the inshore channel intersects traffic lines leading to the habitat of the Lapps [Sámi]" (Sjøvold 1974: 333). The counterpart of the Viking hoards and graves on the coast are the sacrificial sites of the Mountain Sámi where again there is a clear connection to the wealth that was generated from trade (Mulk 1996). The Padjelanta site needs to be viewed in relation to its proximity to the important land route that ran from the upper Lule river valley to Grunnfjord which is connected to Tysfjord. All of this inner coastal area should be seen as a place of transaction between Mountain Sámi, Coastal Sámi, and the Nordic farming, fishing and trading communities of the outer coastal zone, interactions which seem to have intensified from about $600 \mathrm{AD}$ onwards (Hansen 1990; Mulk 1994a).

\section{Sámi boat-building}

As part of their economy the Coastal Sámi of the inner fjords became specialists in boat building, exploiting their control of the pine forests of the inner coastal area. They adopted techniques of clinker construction, sewing the planking with willow roots, and supplying the farming communities with the boats that they needed (Westerdahl 1987). There is a documented example of such exchanges in the Heimskringla of Snorri Sturluson (1138-39), in which Inges saga refers to the a Norse chief on Hinnøya, $100 \mathrm{~km}$ 
north of Tysfjord, who acquired two boats that were built for him during the winter by Sámi living in Gljuvrafjord. These boats were built without nails, and were big enough for twelve oarsmen on each side (Borgos \& Torgvaer 1998: 111).

The boat excavated at Bårset from Nord-Kvaløy, Troms, which dates from around 700, is thought to be of Sámi construction (Gjessing 1941; Reymert 1976). Its length is an impressive $13 \mathrm{~m}$, but it is only $2.7 \mathrm{~m}$ broad and $0.6 \mathrm{~m}$ deep amidships. When viewed from the side the Bårset boat has a similar shape to the smaller boats (Boats 5 and 6) that are depicted at the Padjelanta site, and like these the Bårset boat was rowed and not sailed. It had nine oars on each side and a starboard side-rudder, but no mast. Its construction technique suggests an intermediate stage between rowing boat and sailing boat (Reymert 1976). It may be relevant that the Bårset boat was finally used for funerary rites, and so was preserved archaeologically, an early example of the association of boats with the spirit world which is a persistent theme in both Norse and Sámi cosmology.

The spread to the north of Scandinavian ('Viking') influence after 800 represented a great expansion in trade and in the power of wealthy chiefs. A famous example is Ottar, who voyaged from north Norway to the court of KingAlfred in England about 880-890, boasting of his wealth from 600 tame reindeer, six decoy reindeer used for hunting, and the tribute paid to him by the Sámi (Whitaker 1981; Lund 1984). Viking expansion was in part based on the use of boats of a size and sophistication not previously seen in northern Norway. During the previous period (c. 500-800) these boats had evolved from rowing galleys to ocean-going sailing ships. Small rectangular sails first appear in the Gotland picture stones that are dated to about 600, but fully rigged ships are not seen in Gotland until the 8th century (Varenius 1992; Ellmers 1995). The squaresail started to be used in the 7th century, but ships like Sutton Hoo (c. 625) and Kvalsund (c. 690) were still rowing boats (Westerdahl 1995: 42; Christensen 1996: 79). The first direct evidence in Scandinavia of a mast and rigging comes from the ships preserved at Oseberg (built c. 820) and Gokstad (c. 890), which seem to be specially designed for sailing. It is possible that the pictures of boats 
at the Padjelanta site signal the onset of this maritime technology in north Norway.

However none of these changes in boat technology had any direct effect on the Mountain Sámi. In the post-Viking period, while the Coastal Sámi became increasingly more sedentary, specialising in fishing or adopting animal husbandry and sometimes agriculture, the Mountain Sámi preserved a more ancient economy based on long-distance mobility and an economy of fishing, fur trading and wild reindeer hunting. Mobile bands of hunters used the mountains seasonally, operating from their winter camps that were located along the major rivers and lakes in the foothills zone about $150 \mathrm{~km}$ to the east (Mulk 1994a).

A transition took place in the 16 th century towards reindeer pastoralism, but in terms of boat transport little seems to have changed. Clinker-built boats continued to be an essential item of technology for summer travel by family groups along the big lakes and rivers (Rønbeck 1985; Westerdahl 1987). However the masts, if any, were makeshift and sailing was only an occasional practice. Permanent stays, fixed side-rudders and anchors were not used. Some of these small boats continued to be sailed until the mid-20th century (for photographs see Rønbeck 1985: 10; Mulk 1994a: 238; Borgos \& Torgvaer 1998).

With its tall mast, rigging and broad sails, and its side-rudder and anchor, Boat 4 at Padjelanta appears to be a much more substantial craft than any of the Mountain Sámi boats described historically or recorded in modern times. It does not seem likely, on present evidence, that the Mountain Sámi would have had any use for such boats, although they might well have seen them on their trading expeditions to the Norwegian fjords.

\section{Emergence of the coastal trader}

We can conclude that although direct evidence is lacking, it seems unlikely that specialised sailing boats existed in north Norway until Viking times. After 800 a more complex society emerged in which different types of boat were required for different purposes (Christensen 1996: 83). The longships (karfar, Old Norse) were used 
by the Vikings for warfare. They had masts and sails as well as oars, but probably rowing was their main means of propulsion; these boats were usually beached rather than anchored in deep water (McGrail 1980; Crumlin-Pedersen \& Jørgensen \& Edren 1992; Roberts 1994).

More plausible as a model for the Viking Age boats operating in the fjords of north Norway coast is the knarr, a cargo boat or coastal trader. The earliest evidence for such boats comes from the 10th century, and includes the Äskekärr boat from southwest Sweden (c. 960), the Klåstad boat from south Norway (c. 980) (Westerdahl 1995: 43), and Skuldelev 1 and Skuldelev 3 (c. 1000) from Roskilde in Denmark (Crumlin-Pedersen 1984: 31). These were smaller, broader and heavier types of sailing boat, used primarily for carrying cargo including live animals. Using such boats merchants like Ottar could have carried heavy trade items like whetstones and soapstone alongside lighter goods such as furs, skins, ropes and walrus tusks (Crumlin-Pedersen 1984: 32; Eldjarn 1995). As with all types of boat from the Viking Age, for steering these boats depended on a side rudder mounted on the starboard quarter, and hanging at an angle aft of the vertical of $24^{\circ}-39^{\circ}$ (McGrail 1998: 231; Roberts 1994: 11).

Undoubtedly the Coastal Sámi themselves adopted the sailing boat at this time, and by c. 1000 AD Sámi boatbuilders in the fjords were producing sailing boats for their customers among the farming communities. Indeed it is possible that the origins of the distinctive 'Nordland' boat can be found in the boatbuilding traditions of the Coastal Sámi (Borgos \& Torgvaer 1998). The Nordland boat continued to be built for over 1000 years, and in the early 20 th century it was still used for fishing and coastal transport. Christensen (1982: 21) estimates that its basic design was almost unchanged over nearly 50 generations of boatbuilders, and he attributes this long continuity to a strong conservatism. The boat had a single midship mast, a square sail, six or seven oars per side, and was open from end to end with high stem and stern posts. Only the stern-rudder distinguishes the 20th century Nordland boats from those depicted in Padjelanta. 


\section{Side-rudders and stern-rudders}

The side-rudders that are shown on Boats 3 and 4 at Padjelanta are an important clue to the identity of these boats, but unfortunately we cannot specify an exact date when the side-rudder was no longer used for steering the large boats / small ships operating in north Norway. Elsewhere in Europe, for example in Newcastle, England and at Gotland in the Baltic, the descendents of the Viking ships (Norse type, or keel) were being fitted with stern-post (centre-line) rudders after 1250 (Christensen 1988; Hutchinson 1994; Roberts 1994). However, McGrail (1993: 86, 1998: 251) points out that while some town seals already show these Norse ships with the new stern-rudder (e.g. in Wismar (1256) and Poole (1325)), others show this type of ship as still having a side-rudder (e.g. Faversham and Winchelsea, both early 14th century). In England it is possible that until the Norse ships were superceded by a different type of ship (cog or hulk) the side-rudder continued in general use.

In Scandinavia the picture is also unclear. Boats in the southern Baltic seem to have made the transition to the stern-rudder rather early. The 13th century clinker-built boats preserved at Kalmar castle in Sweden are farmer's boats (storbåtar, Swedish) similar in general proportions to Skuldelev 3 or Padjelanta 3 and 4. These Kalmar boats all have stern-rudders as well as other new features not seen in the Padjelanta boats such as straight stern posts, fore and aft decks and crossbeams protruding throught the sides (Greenhill 1995: 218). Another similar-sized boat from Gedesby in Denmark, dated to c. 1275, also has a stern-rudder (Rieck 1995: 27).

Norway was slower to adopt the new technology, but Brøgger and Shetelig (1971: 181) consider it likely that by 1300 all around the Norwegian coastline the Norse type of cargo boat with side-rudder was being replaced by cogs and hulks with stern-rudders. From 1242 onwards all of the Hanseatic ports, with one exception, have seals that show ships with stern-rudders, this feature serving perhaps as an icon to symbolise their modernity. Bergen became a Hanseatic port, and its town seal of 1299 also shows a stern-rudder on a ship that otherwise is of classic Norse design (Varenius 
1992: 124). By this time Bergen had become the main port for the trade from north Norway, so that in the 14th century the larger cargo ships visiting the Lofoten-Vesterålen region are likely to have had a very different rudder from that shown in Padjelanta Boat 4 . The boats shown by Olaus Magnus in 1555 engaged in cod fishing off the coast of North Norway all have stern-rudders (Olaus Magnus 1982 (1555): 982). However the advantage of the stern-rudder for the smaller Nordland boats operating in the fjords is less clear.

It is not until 1594 that we have the first iconographic evidence for Sámi boats, in the map of a Sámi village on Kildin island, Kola, by the Dutchman van Linschoten (Manker 1963: 15). Three types of boat are depicted. The largest are three-masted sailing ships (galleons), probably from Holland, all carrying large anchors. Secondly there are medium-sized coastal traders, one identified as a Russian 'lodding' (lodja, Swedish) with a midships mast, square sail, bowsprit, stern rudder, and crew of four. Finally, several small Sámi rowing boats are depicted, double-ended and clinker-built, with two men rowing and another using a steering oar in the stern. When not in use the Sámi boats are shown as drawn up on a beach. Although Lofoten-Vesterålen is far from the Kola peninsula, this evidence does tend to confirm that the Padjelanta sailing boats do not match the type of rowing boat that was in everyday use by the Coastal Sámi, even as late as the 16th century.

\section{Anchorages and anchors}

The knarr of the Viking period depended almost entirely on the square-sail for propulsion, and would seldom, if ever, have had its masts unstepped. These coastal traders were too heavy to be beached and therefore needed sheltered harbours where they could be anchored. For the larger boats at least, it seems likely that iron anchors (akkeri, Old Norse) rather than stone anchors (ilasteinur) would have been used, but we have no information about this from northern Scandinavia. What we can say is that it seems highly unlikely that the type of anchor shown in Padjelanta 4 existed in north Norway before the 9 th century.

Hook-shaped iron anchors are known from southern England as early as the 1st century AD (McGrail 1998: 254), but nothing similar exists from Scandinavia until the small anchor found in the 
Oseberg ship burial of 834 (Brøgger \& Shetelig 1953: 98). Anchors with the widely curved arms of the Padjelanta 4 anchor are shown on many of the Viking ships in the Bayeux tapestry, woven around 1070 (McGrail 1998: 255), and the same shape of anchor continued to be used in northern Europe until the end of the Medieval period (Marsden 1996: 130).

However, we have no evidence that such anchors were used on the inland lakes and rivers of the north. To the Mountain Sámi the akkeri shown in Padjelanta 4 was almost certainly an exotic item without a counterpart in their own material culture. The Mountain Sámi were already smelting iron early in the first millennium AD (Mulk 1994a: 7-8), but they were doing so to make small objects like knives and arrow heads. By comparison an iron anchor is a considerably larger object. An assumed Viking Age anchor found in a bog at Bursnesset, Nesna, north Norway weighed about $26 \mathrm{~kg}$ (Shetelig \& Johannessen 1929: 51-52). In the Ladby ship burial in Denmark (900-960) the anchor had a stock $1.2 \mathrm{~m}$ long, arms $0.65 \mathrm{~m}$ wide and an estimated weight of $40-50 \mathrm{~kg}$. A $10 \mathrm{~m}$ iron chain served as a forerunner: it contained about fifty welded links and also weighed more than $40 \mathrm{~kg}$ (Sølver 1946). Bill (1997: 195) has commented that the iron anchors of the Viking ships required advanced smithing techniqes, and they "must have been the largest objects made by smiths in the Viking Age".

It is the stem of Padjelanta 4 that is shown connected to a large anchor, whereas the stern is attached to a mooring line. The layout in this picture partially confirms Brøgger and Shetelig's (1953: 136) suggestion, that Viking ships were not intended to be held by their anchors alone. They suggest that ships like Gokstad and Oseberg voyaged along a coastline during the daytime but made fast ashore every night. Their proposal that "the anchor was dropped from the stern in order to keep the ship clear of land" is contradicted by Padjelanta 4, which, like the Bayeux tapestry and Medieval town seals, shows the anchor line attached to the stem.

\section{Dinghies}

Boat 5 is depicted as a separate rowing boat drifting downwind of the larger sailing boat (Boat 4), and moored to it. In Viking times subsidiary boats of this kind were often kept in tow, as shown by 
their Old Norse name eptirbatr or afterboat (Christensen 1988: 17). The relationship between Padjelanta 4 and 5 is similar to that between the Viking sailing boat and its attached dinghy in the larger of the Winetavern Street sketches from Dublin. These images are scratched on a wooden board and are dated to the period around 1100 (Christensen 1988: 13-19). Although Ireland is apparently remote from north Norway, connections can easily be demonstrated. A Viking ship built in Dublin ended its life as a wreck (Skuldelev 2) in Roskilde harbour (McGrail 1993: 87), while Ottar's voyages demonstrate regular trading connections between north Norway, Denmark and England.

\section{Sails and rigging}

As with anchors and dinghies, the comparisons we can make between the sails and rigging of the Padjelanta boats also come from the wider world of the Viking Age. Our knowledge of sails and rigging, which seldom survive in archaeological contexts, comes mainly from the iconographic evidence of seals, coins, church paintings, picture stones, graffiti and the Bayeux tapestry (McGrail 1980, 1998; von Busch \& Haasum \& Lagerhof 1993; Roberts 1994; Christensen 1988, 1995).According to Christensen (1988: 17) "these illustrations suggest that it must have been common practice to hoist the yard with the furled sail when in harbour, probably in order to keep it clear of the crowded deck of the ship". The furled sail is always depicted by curved or zig-zag lines under the yard. In this respect the Padjelanta boats show a strong resemblance to two pictures of sailing boats scratched on to rocks at Gaudalen in Trøndelag (Table 4) (Sognnes 1980: 19). Trøndelag is $600 \mathrm{~km}$ to the south of the Lofoten-Vesterålen region, and was also an area of Sámi/Nordic interaction during the Viking Age.

The iconographic sources that show sails on Norse boats and ships of the Viking and early medieval periods also show that the set of the rigging was more or less symmetrical fore and aft of the mast. The mast itself was always located in a central midships position. As the mast was not normally unstepped, forestays, backstays and shrouds needed to be permanently set even when the boat was at anchor (McGrail 1998: 231). In this respect also there is a resemblance to what is shown in Padjelanta 3 and 4. 

A
B
C
D
E

\begin{tabular}{|c|c|c|c|c|c|}
\hline & \begin{tabular}{|l} 
Skulde- \\
lev 1
\end{tabular} & $\begin{array}{l}\text { Skulde- } \\
\text { lev } 3\end{array}$ & $\begin{array}{l}\text { Gaudalen } \\
1 \text { and } 2\end{array}$ & $\begin{array}{l}\text { Padje- } \\
\text { lanta } 3\end{array}$ & $\begin{array}{l}\text { Padje- } \\
\text { lanta } 4\end{array}$ \\
\hline $\begin{array}{l}\text { Ratio of mast } \\
\text { height to hull } \\
\text { length }\end{array}$ & $0.7-0.8$ & 0.5 & $0.5-0.4$ & 0.4 & 0.8 \\
\hline $\begin{array}{l}\text { Ratio of yard } \\
\text { length to mast } \\
\text { height }\end{array}$ & $0.9-0.7$ & 0.9 & $2.1-2.2$ & 1.7 & 0.9 \\
\hline $\begin{array}{l}\text { Angle of } \\
\text { rudder }\end{array}$ & $\begin{array}{c}20-26 \\
\text { degrees }\end{array}$ & $\begin{array}{c}17-27 \\
\text { degrees }\end{array}$ & no rudder & $\begin{array}{c}64 \\
\text { degrees }\end{array}$ & $\begin{array}{c}39 \\
\text { degrees }\end{array}$ \\
\hline Forestay & yes & yes & yes & yes & yes \\
\hline Backstay & no & no/yes & yes & yes & yes \\
\hline Shrouds & aft only & aft only & unclear & unclear & $\begin{array}{c}\text { fore and } \\
\text { aft }\end{array}$ \\
\hline Cargo & yes & yes & $\begin{array}{c}\text { no } \\
\text { (except } \\
\text { shields) }\end{array}$ & possibly & $\begin{array}{c}\text { yes } \\
\text { (animals) }\end{array}$ \\
\hline Anchor & $\begin{array}{c}\text { not } \\
\text { known }\end{array}$ & $\begin{array}{c}\text { not } \\
\text { known }\end{array}$ & no & no & yes \\
\hline
\end{tabular}

Table 4. A comparison of some reconstructions of Skuldelev 1 and Skuldelev 3 with sailing boats depicted in rock engravings: two at Gaudalen, Trøndelag, and two at the Padjelanta site.

Sources:

A - Crumlin-Pedersen et al. 1993: 45; Roberts 1994: 14, 17.

B - Crumlin-Pedersen et al. 1993: 45; Roberts 1994: 14, 17.

C-Sognnes 1980: 19; Christensen 1988: 19.

D, E-Tables 1-3, this paper.

\section{Conclusion}

The Viking Age merchant boats seem to provide the closest model to the larger boats depicted at the Padjelanta site. Two examples of such boats were preserved more or less intact (apart from upper masts, rigging and anchors) at Roskilde. Skuldelev 1 is thought to be an ocean-going cargo boat (knarr), similar perhaps to the ones used by Norse chiefs like Ottar (Crumlin-Pedersen 1984). The 
smaller Skuldelev 3 is a small coaster, perhaps the equivalent of the 'great boat' (storbait, Swedish) used by farmers in the Baltic archipelagoes until this century (Crumlin-Pedersen 1996). In its shape and general proportions Skuldelev 3 would appear to be close to the larger boats at Padjelanta (Boats 3 and 4). An exact replica of Skuldelev 3 called Roar Ege has been tested in Danish waters and in the Baltic using sails of woven wool. It needs a crew of four or five men, and can carry 4-5 tonnes of cargo at an average speed of 6.5 knots under favourable conditions (Crumlin-Pedersen 1996: 119).

Our tentative conclusion from the above comparisons is that the boats being portrayed in Padjelanta are similar to the coastal trading boats used on the north Norway coast between 800 and 1300 AD. Transactions took place in the inner coastal area in small fjords such as Grunnfjord and Mellemofjord. We know that a small market was held in mid-October in Grunnfjord up until the 1740s. At that time the Mountain Sámi sold to the Norwegians reindeer and hides and also small items (brass, copper, cloth) purchased from Swedish merchants (Rydving 1993: 47). The earlier history of this market is unknown, but its origins may go back at least to the Viking period. Land routes lead from directly from Grunnfjord eastwards across the mountain area in which the Padjelanta site lies.

Such boats are unlikely to have been seen in the vicinity of Tysfjord until 800 at the earliest, and they were probably replaced by somewhat newer forms in the 14th century. The evidence available cannot provide a closer match, but it does at least suggest that -

the rock engravings of boats at Padjelanta date from during, or just after, the Viking period, c. 800-1300;

the model for the boat figures was probably the kind of boat owned by Norse traders from the outer coastal zone of Lofoten-Vesterålen, or by Coastal Sámi traders from the inner fjord zone; and

such boats are very likely to have been built by the Coastal Sámi in inner fjords such as Tysfjord. 


\section{THE MEANING OF THE PADJELANTA BOATS}

\section{Rock art in the context of trade}

All this indirect evidence suggests some link between the Padjelanta pictures and Sámi/Nordic interaction. Trading contacts enabled the Sámi to portray a new kind of boat in their pictures. Should we therefore assume that the pictures were no more than 'iconic' images, intended simply as 'scale models' of the Nordic boats? The evidence from comparable situations elsewhere suggests that other meanings should also be sought.

In Pictish sites in northern Scotland scratched images have been found on slates, some of them showing Viking boats. O'Meadhra (1993) has argued that we see evidence here of a process thast occurred throughout the northern fringes of Europe, where indigenous groups produced new kinds of images ('graffiti') as a reaction to their contact with persons from a literate world whom they encountered as a result of the outsiders' plundering and trading activities. She believes that in northern Scotland "Pictish sketches occur at a time when an illiterate group with an interest in graphic representation - as witnessed by the symbol stones - first came into contact with the literate West", firstly the Romans, then the Christian church and finally the Vikings (O'Meadhra 1993: 424).

In the case of the Picts we do not know whether or not these images, which appear to new (showing, for example, Viking boats), were in fact just new ways of representing old ideas. In the Great Plains of North America we can better interpret the transition that took place in the rock art following interaction with Europeans in the 18th century (Klassen 1998). A series of changes in the art of Plains Indians followed the introduction of horses, then guns, and finally colonisation. A transition took place in the images, whether on rock surfaces, clothing or tipis, from an 'iconic-symbolic' towards a 'narrative' style. Before the coming of Europeans the pictures consist of isolated, repetitive motifs (animals, weapons, humans), which are interpreted as icons conveying symbolic meanings: "they do not evoke a specific time, place or event, but rather evoke the eternal present of the spirit world" (Klassen 1998: 45). After European contact this 'cosmic' view of the world begins to change. We 
see in the art many of the same motifs as before, but also some new ones (e.g. horses, guns). These are combined to create narratives that seem intended to represent actual people and events.

At the same time we can infer a substantial degree of cultural continuity among Plains Indians from the continued depiction in their art of traditional motifs like the shield. The 19th century ethnography shows that the shield functioned symbolically as an object invested with supernatural powers to protect its owner in battle (Klassen 1998: 47). Such meanings were not at first affected by European contact. It was only at a later stage in North America that the 'cosmic' conception of the world was replaced by an entirely 'historical' view. For example, at the point when the Micmac Indians of Nova Scotia became Christians and totally dependent on the fur trade, their rock art begins to portray specific objects and events in Micmac life (horses, soldiers, ships, names and dates). These replace the images of animals such as moose which were metaphors for spiritual relationships within the old 'non-historical' world-view (Molyneaux 1987).

For the Mountain Sámi, it may be useful to consider the boat motif in a similar way. Athough its roots are much older, the fur trade was leading to an intensified process of cultural interchange around 1000 AD. By c. 1600 new Christian symbols as well as more traditional motifs such as reindeer and boats were being incorporated into the images drawn on Sámi drums (Rydving 1991: 35). We may be seeing graphic evidence of an earlier stage of this process of symbolic incorporation in the Padjelanta pictures. But although boats were now being depicted in new ways, are we actually seeing in the art in Padjelanta a continuity in symbolic meanings?

\section{Semiotics of the Padjelanta boats}

Our identification of the type of boat portrayed at the Padjelanta site provides us with an historical context through which we can approach the meaning of the pictures. However some fundamental semiotic questions still need to be asked. Are these pictures merely 'art for art's sake', or accurate 'scale models' that were designed to show to a curious admiring audience what real Viking ships were like? If so, then the boat pictures served merely as icons, a type of sign whose relationship to the object being portrayed can be de- 
duced from the icon's own characteristics (Lewis-Williams 1981: 4). In the case of rock art the less access we have to supplementary information, for example from ethnography, the easier it is to suppose that the art is purely iconic, and that its meaning is self-contained and straightforward.

The alternative view looks beyond the iconic meaning of a sign and considers its deeper cultural meaning. A painting does not have to be wholly 'abstract' for it to contain cryptic meanings, and even the most realistically portrayed boat or animal can be an icon fulfilling a symbolic purpose. In rock art the presence of icons functioning as symbols is powerfully argued by Lewis-Williams (1981: 75) in his analysis of the meaning of the eland antelope in the rock paintings of the southern San in South Africa. He argues that

[Some of] ... the graphic signs ... [are], at their simplest level, iconic in that they exhibit a visual similarity to their objects; these objects were observable elements in nature - people and animals. ....[Other paintings] deal with an activity which links the totality of society with an analeptic power. I argue that some of the paintings are associated with that activity and ... are not iconic since they do not signify natural objects but depict imagined or even hallucinatory entities: conceptual and visionary forms translated into graphic representations. (Lewis-Williams 1981: 75).

Were boats for the Sámi, like eland for the San, signs which simultaneously represented both the iconic and the symbolic? At one level the Padjelanta pictures show Viking trading or farm boats, complete with rudders, sails and anchors, but at the same time can these pictures also be seen as metaphors for something more conceptual and visionary?

\section{Establishing a mythic and ritual context}

To assess the symbolic meaning of boats in any culture we need to know in more detail the mythic and ritual context in which the representation of boats played some part (Schjødt 1995: 24). As Nordbladh (1978: 67) has emphasised in relation to Scandinavian petroglyphs, "an isolated image can mean anything". Only if we establish a context for a prehistoric image can we hope to under- 
stand the meaning of the message that the image was originally intended to convey. However, in the case of the pre-Christian Sámi we face the problem of an almost total absence of secure ethnography upon which to base an analysis of the particular semantic field in which a picture of a boat gave rise to certain associations.

Sámi myths contain some detailed references to travel in sailing boats, particularly in stories of the Sun's Son (Peiven Parneh) that were first recorded by the Sámi priest Anders Fjellner in the mid19th century (Lundmark 1979). Sámi religious beliefs are another area in which the boat metaphor plays a role.

Beliefs in the period since c. 1600 have been examined in exhaustive detail, using the scattered and fragmentary written sources, and through an analysis of the figures depicted on the shamans' drums (e.g. Bäckman \& Hultkrantz 1985; Ahlbäck 1987; Rydving 1993). However these reconstructions of religious belief refer to the period after the transition from hunting to herding, and relate also to a period of intense confrontation between Sámi and nonSámi cultures, on the frontiers of Swedish, Norwegian and Russian colonial expansion. We believe that the Padjelanta rock art dates from an earlier period, when the economy of the Mountain Sámi was based on hunting, fishing and the fur trade. For this period both historical and archaeological sources are sparse, so that any attempt to make statements about the symbolic meaning of boats must be based more on analogy than any direct use of evidence.

This difficult task will not be undertaken in this paper, and would in any case require the pictures of boats to be viewed in relation to the other juxtaposed and superimposed figures on the rocks at the Padjelanta site rather than them being analysed in isolation. However, in order to indicate possible directions for future work which (unlike this paper) would extend beyond the iconic meaning of the boats at Padjelanta, we draw attention to three possible lines of enquiry: ethnography, iconography and archaeology.

\section{Ethnographic evidence for symbolic meanings}

One of the very few early writers who mentions the symbolic meaning of boats is Samuel Rheen in 1666-1671. His account of the 
Lule Sámi includes information about their midwinter practices and beliefs. On the day announced by the priests as Christmas Day, in Sámi households

...[M]orsels of food would be set aside ... and put into a container of birch bark which is formed in the shape of a boat equipped with a mast and oars, and on top of this they pour a little fat. The container they then place about a musket shot from their tents in a tree; this they wish to give to the errant Christmas folk [spirits of the dead] who they believe wander abroad in the air (Rheen 1897: 27. Translation: Fjellström 1987: 35).

Fjellström (1987: 41) sees a parallel between this Christmas offering and the sacrifices that the Lule Sámi made at the winter solstice to the god of the wind (Bieggålmaj), and also to water spirits (Tjatje-halde). She suggests that the boat symbol spread to the Lule Sámi through the contacts they maintained with the Coastal Sámi in north Norway. She further believes that the cult of sacrificial boats among the Coastal Sámi was derived from Nordic contacts in the period after $500 \mathrm{AD}$.

In fact it seems more likely that the ancestors of the Lule Sámi had developed and maintained their own boat symbolism over a much longer period. Symbolic-ideological continuity is also suggested by Helskog $(1985,1987)$ in his studies of the rock engravings at Alta fjord, north Norway. Boats are important motifs at Alta from 4200 $\mathrm{BC}$ onwards, but the type of boat changes in the most recent period (ca. 1700-500 BC). Changing boat technology matches evidence for other socio-economic changes in Finnmark at this time, including the first traces of agriculture. However it is significant that boats continue to be chosen by the hunter-fisher societies at Alta for representing what Helskog believes were rituals connected to travelling and the spirit world, in other words as "carriers of the gods" (Helskog 1985: 197-8).

These ideas open up the possibility that to the Sámi in the Scandes mountains around $1000 \mathrm{AD}$, Viking sailing boats were icons functioning as symbols, and having strong associations with the spirit world. A similar continuity in beliefs is proposed by Simonsen (1969) for Varanger fjord in east Finnmark. The mountain peak at Álda, on the north side of Varanger, was still being used by the Sámi for 
offerings to the god Steinjunkeren until it was desecrated by a Norwegian missionary in 1718 . There are rock faces on Álda engraved with human figures, reindeer and a sailing ship (Simonsen 1970: 184-5). For Padjelanta, where we see the same combination of motifs, we cannot at present demonstrate a direct link to a Sámi sacred site, but the possibility of a connection in Padjelanta between the boat symbol and the spirit world deserves further consideration.

\section{Iconographic evidence from drums}

A second line of enquiry is the boat motif on Sámi shamans' drums, more than seventy of which have survived, dating from the 17th and 18th centuries (Helskog 1987). Ernst Manker (1950) provides illustrations of 72 drums, and among the figures depicted on their skins are many boats. These are clearly recognisable from their curved and often symmetrical hulls, masts, rigging and yards (Manker 1950: 56-7).

The first historical source to give a description of a Sámi drum in use is Historia Norwegiae (c. 1190), and it provides crucial evidence of the boat as a shamanistic metaphor. The chapter entitled De Finnis (on the Sámi) includes what may well be an eye-witness account of a shaman using the drum to go into trance. According to this source, the drum "is adorned with small drawings of whales and reindeer with reins, small skis and also a small boat with oars (navicula cum remis); the spirit helping him (the shaman) would use these to get through deep snow, over steep mountains and across deep waters" (Haetta 1994: 20; Bäärnhielm \& Zachrisson 1994: 163). It would seem that the original function of the drum and its motifs was to assist the shaman when he needed to fall into trance so as to make an ecstatic journey.

Manker suggests a provenance for each surviving drum, the majority of which derive from the South and Central Sámi area. If we examine those drums that are thought to derive from the Nordland and Nord-Trøndelag regions of north Norway we find that without exception they show boats, whereas none of the drums from Finnmark and rather few of those from further south include this symbolic motif. Some of the drums contain two different types of boat each in a characteristic position. In the upper part of the drum 
we find boats with masts and rigging, and the resemblance between some of these and the boat figures from Padjelanta is very striking. In the lower half of the drums the boats appear to be rowing boats with a more practical use for hunting or fishing.

Unfortunately the precise meaning of boats to those who made the drums is unknown. In the historical sources there exist only two accounts by Sámi that give some information about the meaning of the various motifs as understood by the actual owners of drums (Rydving 1991). Only one of these accounts includes any mention of a boat. It relates to Mankers's drum 30, where there is a boat with mast, fore- and backstays, bowsprit and cut-off stern. In the early 18th century the Sámi owners of this drum, which had been in their family for generations, described this motif as simply representing 'the ferry boat' (Rydving 1991: 37, 39).

Since Sámi drums in the 18th century were being used for divination as well as for trance, perhaps all the motifs were intended to be ambiguous and polysemic, conveying to drum users different meanings in different contexts. In any case, in a situation of intense confrontation between Sámi and the Church, few of these meanings would be divulged to outsiders. Modern scholars have generally emphasised mythological, shamanistic or astrological interpretations for the various drum motifs. Lundmark (1982: 3946), for example, points to a persistent connection between the boat symbol and the Sámi moon cult. Like Manker, he believes that Rheen's observations of the Christmas-time customs of the Lule Sámi provide us with a meaning for the boats depicted on drums, which were intended to symbolise the spirits of the dead.

Sommarström (1987: 237-46) has identified a persistent pattern in the positioning of the various motifs on Sámi drums. For the boat motif there is a strong correlation between its location on drums and the position occupied on star maps by the constellation Sagittarius. In European astrology Sagittarius was also one of the zodiac signs, and it seems very possible that Sagittarius, represented by a boat, also had this symbolic association in the Sámi cosmology. Sommarström (1991: 159) goes on to show that in the latitude of Padjelanta Sagittarius does not rise above the horizon during the first seven months of the year, and achieves its greatest visiblity in the southern sky during September. August, September and 
October are the months when reindeer hunters are most likely to have visited the Padjelanta site. Is it a coincidence that the rock surface with the boats faces due south, towards the night sky where Sagittarius was visible?

We do not know the precise significance to the Sámi of the association between Sagittarius and the boat symbol, and nor do we know for sure if the various zodiac signs shown on the drums are anything more than a star map to help the drum user to position his drum in astrological space. Moreover, while the reference in Historia Norvegiae (c. 1190) to use of the boat symbol on a shaman's drum is more or less contemporary with the Padjelanta boat pictures, the surviving drums are later, and incorporate many new ideas, including Christian motifs. It is clear that graphical metaphors were undergoing a process of indigenous development. As Rydving (1991: 35) points out, "the few figures on the drum described in Historia Norvegiae are in sharp contrast to the rich world of figures on the drums preserved".

Although difficult to interpret, the evidence does point to the likelihood that the sailing boats had connections to shamanism, divination and funeral rites, or to sacricial offerings during the autumn season. It is likely that the boats at Padjelanta would have been understood as metaphors for travel to another world in which ancestor spirits were living.

\section{Archaeological evidence of boat burials}

Most of the ethnographic sources and information about the drums' iconography relate to a later period than our suggested date for the Padjelanta boats (c. 800-1300). However, there is also archaeological evidence which, although it comes from the wider region rather than the site itself, is at least contemporary with the pictures in Padjelanta. Like the other two sources, the archaeology suggests a symbolic link between boats and the spirits of the dead.

Several examples exist from the Lofoten-Vesterålen coastal area of boats or ships being used for burials. For example, at Øknes Prestgård in the Lofoten Islands, a funeral boat was found measuring 8-10 $\mathrm{m}$ in length and dating to the 9th century (Johansen 1976). Direct evidence that the Coastal Sámi shared in this cult of 
boat burials comes from Salten fjord, where a well-preserved skeleton classified as Sámi was found in a boat burial (Stenvik 1980).

There therefore exists the possibility that the Padjelanta site itself is situated not far from Sámi graves, and that the human/animal figures in Boat 4 are intended to represent dead persons travelling to an afterlife. Tomas Partapuoli, a reindeer herder from Sirkas Sameby, has recently spoken about a tradition that there existed traces of Sámi graves among rocks quite close to the Padjelanta rock engravings (interview with I. M. Mulk, 1999). This new evidence strengthens our suggestion that the boat figures were intended to convey spiritual as well as iconic meanings.

\section{CONCLUSION}

These indications of a strong association between the boat symbol and Sámi religious beliefs, shamanism and funeral rites, constitute a body of evidence that casts doubt on the assumption that the Padjelanta boats are merely iconic. As icons, they contain information which suggests that the boats that are represented were those that belonged to Nordic traders and farmers operating in the fjords of north Norway in the period c. 800-1300. It is likely that boats of this kind were being built by the Coastal Sámi of the inner fjords. However, it is also likely that the total meaning of the boat figures to the Mountain Sámi went well beyond their ostensible purpose as simple icons. A full interpretation of their symbolic meaning will require more information from the site itself and from its surrounding area, and also a deeper analysis of the wider cultural and geographical context.

\section{Acknowledgements}

For their participation in the fieldwork at the Padjelanta site in 1992, 1993 and 1998, we thank in particular Lennart Nordquist, Irene Partapuoli, Tomas Partapuoli and Anders Lindberg. For financial assistance we are grateful to Ájtte Museum, the Göran Gustafsson Foundation, St. John's College, Cambridge, and the Scandinavian Studies Fund of Cambridge University. For valuable comments on earlier drafts of the paper we thank Neil Price and Inger Zachrisson, and the participants at the conference "Människor 
och båtar i Norden" held at the Sjöhistoriska museet, Stockholm, 29-31 May 1998, at which an earlier version of this paper was presented. We also thank Knut Helskog and Chris Chippindale for their comments at seminar presentations given by us in Alta and Cambridge, respectively.

\section{References}

Ahlbäck, T. (Ed.) 1987. Saami religion. Åbo.

Bakka, E. 1975. Geologically dated rock carvings at Hammer near Steinkjer in Nord-Trøndelag. Arkeologiske Skrifter fra Historisk Museum, Universitet i Bergen 2, pp. 7-48.

Bayliss-Smith, T. \& Mulk, I. M. 1998. Segelbåtar i Padelanta. Samiska hällristningar från järnålder och medeltid i Laponia, Lappland. In Sjöhistoriska museet, Människor och båtar $i$ Norden. Maritime History Museum. Stockholm, pp. 39-51.

Bill, J. 1997. Ships and seamanship. The Oxford illustrated history of the Vikings. Ed. by P. Sawyer. Oxford, pp. 182-201.

Borgos, J. I. \& Torgvaer, T. 1998. Samer og båtbygging. Människor och båtar $i$ Norden (Sjöhistorisk Årsbok 1998-1999). Stockholm, pp. 104-115.

Brøgger, A. W. \& Shetelig, H. 1953. The Viking ships, their ancestry and evolution. Oslo.

Bäckman, L. \& Hultkrantz, A. (Eds.) 1985. Saami pre-Christian religion. Studies on the oldest traces of religion among the Saami. (Acta Universitatis Stockholmensis 5, Studies in Comparative Religion 25). Stockholm.

Bäärnhielm, G. \& Zachrisson, I. 1994. De Finnis, "Om samerna”, ur Historia Norvegiae ca 1190 B.C. Fornvännen 89, pp. 161-164.

von Busch, P. \& Haasum, S. \& Lagerhof, E. 1993. Skeppristningar på Gotland. Stockholm.

Christensen, A. E. 1982. Viking age ships and shipbuilding. Norwegian Archaeological Review 15 (1-2), pp. 19-28.

Christensen, A. E. 1988. Ship graffiti and models. Medieval Dublin Excavations 1962-81, Miscellanea 1 (ser. B, vol. 2). Dublin, pp. 13-26.

Christensen, A. E. 1995. Ship graffiti. The ship as symbol in prehistoric and medieval Scandinavia. Ed. by O. Crumlin-Pedersen \& B. M. Thye. (Studies in Archaeology and History 1). Copenhagen, pp. 180-185. 
Christensen, A. E. 1996. Proto-Viking, Viking and Norse craft. The earliest ships. The evolution of boats into ships. Ed. by A. E. Christensen. London, pp. 2-88.

Coles, J. 1994. Rock carvings of Uppland. A Guide. Uppsala.

Crumlin-Pedersen, O. 1984. Ships, navigation and routes in the reports of Ohthere and Wulfstan. Two voyagers at the Court of King Alfred. Ed. by N. Lund. York, pp. 30-42.

Crumlin-Pedersen, O. \& Jørgensen, M. S. \& Edren, T. 1992. Skibe og samfaerdsel. In Nordisk Ministerråd, Viking og Hvidekrist. Norden og Europa 800-1200. Uddevalla, pp. 42-51.

Crumlin-Pedersen, O. 1996. Problems of reconstruction and the estimation of performance. The earliest ships. The evolution of boats into ships. Ed. by A. E. Christensen. London, pp. 110-119.

Eldjarn, G. 1995. Litt om båtar og skip på Ottars tid. Ottar, Tromsø Museum, 5-1995, nr. 208: 28-30.

Ellmers, D. 1995. Valhalla and the Gotland stones. The ship as symbol in prehistoric and medieval Scandinavia. Ed. by O. CrumlinPedersen \& B. M. Thye. (Studies in Archaeology and History 1). Copenhagen, pp. 165-71.

Fjellström, P. 1987. Cultural- and traditional-ecological perspectives on Saami religion. Saami religion. Ed. by T. Ahlbäck. Åbo, pp. 34-45.

Gjessing, G. 1941. Båtfunnene fra Bårset og Öksnes. To nordnorske jernalderfunn. (Troms $\emptyset$ Museums Årshefter, kulturhistoria avd. No 8, vol. 58, 1935). Troms $\emptyset$.

Greenhill, B. 1995. The archaeology of boats and ships: an introduction. London.

Haetta, O. M. 1994. The ancient religion and folk-beliefs of the Sámi. Alta.

Hallström, G. 1960. Monumental art of northern Sweden from the Stone Age. Nämforsen and other locations. Stockholm.

Hansen, L. I. 1984. Trade and markets in northern FennoScandinavia A.D. 1550-1750. Acta Borealia 1(2): 47-79.

Hansen, L. I. 1990. Sámisk fangstsamfunn og norsk høvinekeønomi. Oslo.

Helskog, K. 1985. Boats and meaning: a study of change and continuity in the Alta fjord, Arctic Norway, from 4200 to 500 years B.C. Journal of Anthropological Archaeology 4: 177-205.

Helskog, K. 1987. Selective depictions. A study of 3,500 years of rock carvings from Arctic Norway and their relationship to the Sami 
drums. Archaeology as long-term history. Ed. by I. Hodder. Cambridge, pp. 17-30.

Hutchinson, G. 1994. Medieval ships and shipping. London.

Johansen, O. S. 1976. Tidlig nordnorsk båthistorie. Ottar, Troms $\emptyset$ Museum, Nr. 89: 33-7.

Jørgensen, R. \& Olsen, B. 1987. Asbestkeramik i Nord Norge. Finskt Museum 94: 5-39.

Kolsrud, K. 1961. Sommarsete. Til problemet om halvnomadism og seterflyttning blant norske sjøsamer. Sámiske samlinger 5. Oslo, pp. 1-74.

Klassen, M. A. 1998. Icon and narrative in transition: contactperiod rock-art at Writing-On-Stone, southern Alberta, Canada. The Archaeology of Rock-Art. Ed. by C. Chippindale and P. S. C. Tacon. Cambridge: Cambridge University Press, 42-72.

Lewis-Williams, J. D. 1981. Believing and seeing. Symbolic meanings in southern San rock paintings. London.

Lund, N. (Ed.) 1984. Two voyagers at the court of King Alfred. The ventures of Ohthere and Wulfstan together with the description of Northern Europe from the Old English Orosius. York.

Lundmark, B. 1979. Anders Fjellner - Samernas Homeros och dikningen om solsönerna. Acta Bothniensia Occidentalis, Skrifter i väasterbottnisk kulturhistoria. Umeå.

Lundmark, B. 1982. Baei'vi mánno nástit. Sol och månkult samt astrala och celesta föreställningar bland samerna. Studier $i$ norrländsk forntid. Acta Bothniensia occidentalis, Skrifter $i$ västerbottnink kulturhistoria 5 . Umeå.

Mallmer, M. P. 1989. Bergkonstens mening och innehåll. Hällristningar och hällmålingar $i$ Sverige. Ed. by S. Janson, E.B. Lundberg \& U. Bertilsson. Helsongborg, pp. 9-28.

Manker, E. 1950. Die Zaubertrommel II. Die Trommels als Urkunde Geistigen Leben. (Acta Lapponica 6). Stockholm.

Manker, E. 1957. Lapparnas heliga ställen. Kultplatser och offerkult $i$ belysing av Nordiska museets ock lantantikvariernas fältundersökningar. (Acta Lapponica 13). Stockholm.

Manker, E. 1963. De Åtta Årstidernas Folk. Göteborg.

Marsden, P. 1996. Ships of the Port of London, twelfth to seventeenth centuries $A D$. (English Heritage, Archaeology Report 5). London.

McGrail, S. 1980. Ships, shipwrights and seamen. The Viking world. Ed. by J. Graham-Campbell. London, pp. 36-63 
McGrail, S. 1993. Medieval Dublin Excavations 1962-81. Medieval boat and ship timbers from Dublin. (ser. B, vol.3). Dublin.

McGrail, S. 1998. Ancient boats in North-West Europe. The archaeology of water transport to $A D$ 1500. 2nd edn. London and New York.

Moe, D. 1991. Hustad, Arstad and Naurstad. A vegetational study of three farms in Salten, North Norway. Norsk Geografisk Tiddskrift 45: 11-24.

Molyneaux, B. 1987. Concepts of humans and animals in postcontact Micmac rock art. Animals into Art. Ed. by H. Morphy. London, pp. 193-214.

Mulk, I. M. 1988. Sirkas: ett Sámisk fångstsamhälle i förändring 500-1500 e.Kr. Bebyggelsehistorisk Tidskrift, Uppsala, 14/1987: 6174.

Mulk, I. M. 1994a. Sirkas - ett Sámiskt fångstsamhälle i förändring Kr.f. - 1600 e.Kr. Umeå.

Mulk, I. M. 1994b. Sacrificial places and their meaning in Saami society. Sacred sites, sacred places. Ed. by D. Carmichael, J. Hubert, B. Reeves \& A. Schanche. London, pp. 121-131.

Mulk, I. M. 1996. The role of the Sámi in fur trading during the Late Iron Age and Nordic Medieval period in the light of the Sámi sacrificial sites in Lapland, northern Sweden. Acta Borealia 13: 47-80.

Mulk, I. M. 1998. Nyfunna hällristningar avbildar samiska segelbåtar. Populär Arkeologi 16 (4): 23-25.

Mulk, I. M. \& T. P. Bayliss-Smith 1998. The representation of Sámi cultural identity in the cultural landscapes of northern Sweden: the use and misuse of archaeological evidence. The Archaeology and Anthropology of landscape. Ed. by P. J. Ucko \& J. Layton. London, pp. 358-396.

Mulk, I. M. \& Bayliss-Smith, T. P. \& Nordqvist, L. 1998. Rapport över dokumentationer av hällristningar från järnålder och medeltid i Padjelanta, Jokkmokks sn., Lappland. Ájtte, Svenskt Fjäll- och Samemuseum, Jokkmokk.

Nesheim, A. 1967. Eastern and Western elements in Lapp culture. In - Instituttet for Sammenlignende Kulturforskning, Oslo, Serie A, Nr. 26, Lapps and Norsemen in olden times. Oslo, pp. 104168.

Nielssen, A. R. 1990. Fra steinalderen til 1700-talet. Lødingen, Tjeldsund og Tysfjords historie 4. Bodø. 
Nordbladh, J. 1978. Images as messages in society. Prolegomena to the study of Scandinavian petroglyphs and semiotics. New Directions in Scandinavian Archaeology (Studies in Scandinavian Prehistory and Early History Vol. 1). Ed. by K. Kristiansen \& C. Paludan-Müller. Copenhagen, pp. 63-68.

Odner, K. 1983. Finner og terfinner. Etniske prosesser $i$ det nordlige Fenno-Scandinavia. Occasional Papers in Social Anthropology 9. Oslo.

Odner, K. 1985. Sámis (Lapps), Finns and Scandinavians in history and prehistory. Norwegian Archaeological Review 18 (1-2): $1-35$.

Olaus Magnus 1982 (1555). Historia om de Nordiska Folken deras olika Förhållanden... (Roma). Malmö.

O’Meadhra, U. 1993. Viking-Age sketches and motif-pieces from the northern earldoms. The Viking Age in Caithness, Orkney and the North Atlantic. Ed. by C. E. Batey \& J. Jesch \& C. D. Morris. Edinburgh, pp. 423-440.

Ramqvist, P. H. 1989. Ångermanland, Västerbotten och Lappland. Hällristningar och hällmålingar $i$ Sverige. Ed. by S. Janson, E. B. Lundberg \& U. Bertilsson. Helsingborg, pp. 213223.

Reymert, P. K. 1976. Båretbåten - spor etter Sámisk-norsk kukturblanding? Ottar, Tromsø Museum, Nr. 89: 30-2.

Rheen, S. [1671] 1897. En kortt Relation om Lapparner Lefwarne och Sedher, wifd-skiepellser, samt i många stycken Grofwe wildfarellsser. Nyare bidrag till kännedom om de svenska landsmålen och svensky folklif 17.1. Ed. by K. B. Wiklund. Stockholm.

Rieck, F. 1995. Institute of MaritimeArchaeology - the beginning of maritime research in Denmark. Shipshape. Essays for Ole Crumlin-Pedersen. Ed. by O. Olfsen \& J. S. Madsen \& F. Rieck. Roskilde, pp. 19-36.

Roberts, O. T. P. 1994. Descendants of Viking boats. Cogs, caravels and galleons. The sailing ship 1000-1650. Ed. by R. Gardiner. London, pp. 11-28.

Rydving, H. 1991. The Saami drums and the religious encounter in the 17th and 18th centuries. The Saami Shaman Drum. Ed. by T. Ahlbäck and J. Bergman. Scripta Instituti Donneriana Aboensis 14. Donner Institute, Åbo, Finland, 28-51.

Rydving, H. 1993. The end of drum-time. Religious change among the Lule Saami, 1670s-1740s. Uppsala. 
Rønbeck, N.-F. 1985. Elvebåten. Ottar, Troms $\emptyset$ Museum, 1985/ 3, Nr. 154, 3-48.

Serning, I 1956. Lapska offerplatsfynd från järnålder och medeltid $i$ de svenska lappmarkerna. Acta lapponica 11. Uppsala.

Schjødt, J. P. 1995. The ship in Old Norse mythology and religion. The ship as symbol in prehistoric and medieval Scandinavia. Ed. by O. Crumlin-Pedersen \& B. M. Thye. (Studies in Archaeology and History 1). Copenhagen, pp. 20-24.

Shetelig, H. \& Johannessen, F. 1929. Kvalsundfundet og andre norske myrfund av fartøier. Bergens Museet Skrifter. Ny Rekke. Bind II, Nr. 2. Bergen.

Simonsen, P. 1969. Ny bergkunst fra Finnmark. Ottar, Tromso Museum, 1969/3, Nr. 61, pp. 12-19.

Simonsen, P. 1970. Fortidminner nord for polarsirkelen. 2nd edn. 1991. Oslo.

Sjøvold, T. 1962. The Iron Age settlement of Arctic Norway. A study of the expansion of European Iron Age culture within the Arctic Circle. Troms $\emptyset$, Oslo.

Sjøvold, T. 1974. The Iron Age settlement of Arctic Norway. A study of the expansion of Iron Age culture within the Arctic Circle. II. Late Iron Age. (Troms $\emptyset$ Museums Skrifter vol. X. 2). Troms $\emptyset$, Oslo and Bergen.

Sognnes, K. 1980. Båter i berg. Båttradisjoner i Trøndelag gjennom 3500 år. Spor-fortidsnytt fra midt-norge, 3(5), Nr. 1: 1921.

Sognnes, K. 1998. Symbols in a changing world: rock-art and the transition from hunting to farming in mid Norway. The archaeology of rock-art. Ed. by C. Chippindale and P. S. C. Tacon. Cambridge, pp. 146-162.

Sølver, C. V. 1946. The Ladby ship anchor. Acta Archaeologica 17:117-126.

Sommarström, B. 1987. Ethnoastronomical perspectives on Saami religion. Saami religion. Ed. by T. Ahlbäck. Åbo, Finland, pp. 211-50.

Sommarström, B. 1991. The Saami shaman's drum and the star horizons. The Saami Shaman Drum. Ed. by T. Ahlbäck and J. Bergman. Scripta Instituti Donneriani Aboensis 14. Donner Institute, Åbo, Finland, 136-168.

Stenvik, L. F. 1980. Samer og nordmenn sett i lys av et uvanlig jernalders gravfunn fra Saltenområdet. Viking 43, 1979: 127-39. 
Storli, I. 1993. Sámi Viking Age pastoralism - or 'the Fur Trade paradigm' revisited. Norwegian Archaeological Review 26 (1): 120 .

von Sydow, U. 1982. Vegetationskarta över de svenska fjällen. Kartblad nr. 4, Sitasjaure (29G/29H/30H). Stockholm.

Westerdahl, C. 1987. "Et sätt som liknar them uti theras öfriga lefnadsat”. On aldre Sámist båtbygge och Sámisk båthantering. Umeä: Skrifter utgivna av Johan Nordlander-sällskapet, Nr. 11.

Westerdahl, C. 1995. Society and sail. On symbols as specific social values and ships as catalysts of social units. The ship as symbol in prehistoric and medieval Scandinavia. Ed. by O. CrumlinPedersen \& B. M. Thye. (Studies in Archaeology and History, vol. 1). Copenhagen, pp. 41-50.

Whitaker, I. 1981. Ohthere's account reconsidered. Arctic Anthropology 18: 1-10.

Whitaker, I. 1983. Late Classical and early Medieval accounts of the Lapps (Sámi). Classica et Mediaevalia 34: 283-303.

Wiklund, K. B. 1947. Lapparna. Stockholm Nordisk kultur 10.

Varenius, B. 1992. Det Nordiska Skeppet. teknologi och samhällsstrategi $i$ vikingatid och medeltid. (Stockholm Studies in Archaeology 10). Stockholm.

Vorren, K. D. \& Nilssen, E. \& Mørkved, B. 1990. Age and agricultural history of the '-stadir' farms of North and Central Norway. Norsk Geografisk Tiddsskrift 44: 79-102. 